\title{
Impact Of Tourism On Community Development And Income In Kuta Mandalika Beach Kuta Village, Pujut District, Central Lombok
}

\author{
Abdul Haris, Nurul Hidayati Indra Ningsih, \\ STIKES YARSI Mataram ${ }^{1}$, Universitas Muhammadiyah Mataram²
}

\begin{abstract}
Tourism is one of the sectors that provides the largest contribution to national economic growth so the government pays special attention to its development. One form of tourism development program in West Nusa Tenggara Province is the development of Kuta Beach as one of the Mandalika Special Economic Zones (KEK). The development of tourism has an impact or influence on the community around the area. The research problem is formulated as follows: How is the impact of tourism on community development in Kuta Mandalika Beach Kuta Village, Pujut District, Central Lombok? 2) What is the impact of tourism on community income in Kuta Mandalika Beach, Kuta Village, Pujut District, Central Lombok? This research is a qualitative descriptive study with data collection techniques in the form of interviews, observations, and documentation. This study describes the development of tourism by examining a group of people, namely groups of tourism businesses in the vicinity of the Mandalika Kuta Beach Area. The aim is to find out whether there are changes that occur in terms of community development in the economic, socio-cultural, environmental and community income from tourism development. The results showed that tourism had an impact on community development in Kuta Mandalika Beach, Kuta Village, Pujut District, especially in the economic, social cultural and environmental fields. In addition, tourism also impacts on people's income through increased business capacity in the tourism sector, such as hotels, restaurants, tour guides, travel agencies, shops and tourism service businesses, but it has a decreased impact on business capacity for craft / artshop tourism businesses, hawkers / Street vendor.
\end{abstract}

\section{Keywords: Tourism, Impact, Development, Income, Community}

Abstrak. Pariwisata adalah salah satu sektor yang memberikan kontribusi terbesar dalam pertumbuhan ekonomi nasional sehingga pemerintah memberikan perhatian khusus dalam pengembangannya. Salah satu bentuk program pengembangan pariwisata di Provinsi Nusa Tenggara Barat adalah dengan dikembangkannya Pantai Kuta sebagai salah satu Kawasan Ekonomi Khusus (KEK) Mandalika. Pengembangan pariwisaata akan memberikan dampak atau pengaruh terhadap masyarakat di sekitar Kawasan sehingga Penelitian ini penting untuk dilakukan di Kawasan Pantai Kuta Mandalika Desa Kuta Kecamatan Pujut Kabupaten Lombok Tengah. Adapun rumusan masalah penelitian ini adalah 1). bagaimanakah dampak pariwisata terhadap pengembangan masyarakat di Pantai Kuta Mandalika Desa Kuta Kecamatan Pujut Lombok Tengah. 2). Bagaimanakan dampak pariwisata terhadap pendapatan masyarakat di Pantai Kuta Mandalika Desa Kuta Kecamatan Pujut Lombok Tengah. Metode dalam penelitian ini menggunakan jenis penelitian deskriptif kualitatif. Dengan teknik pengumpulan data yang digunakan dalam penelitian ini adalah teknik wawancara, observasi dan dokumentasi. Penelitian ini akan mendiskripsikan pengembangan pariwisata dengan meneliti sekelompok masyarakat yaitu kelompok pelaku usaha pariwisata yang berada disekitar Kawasan Pantai Kuta Mandalika untuk mengetahui apakah ada perubahan yang terjadi dalam kelompok masyarakat tersebut dari segi pengembangan masyarakat dalam bidang ekonomi, sosial budaya, lingkungan dan pendapatan masyarakat dari adanya pengembangan pariwisata. Hasil penelitian menunjukkan bahwa pariwisata berdampak terhadap pengembangan masyarakat di Pantai Kuta Mandalika Desa Kuta Kecamatan Pujut khususunya dalam bidang ekonomi, sosial budaya dan lingkungan. Selain itu pariwisata juga berdampak terhadap pendapatan masyarakat dari peningkatan kapasitas usaha untuk pelaku usaha pariwisata hotel, restoran, pemandu wisata, biro perjalanan, toko dan usaha jasa pariwisata dan memberikan dampak penurunan terhadap kapasitas usaha bagi pelaku usaha pariwisata kerajinan/artshop, pedagang asongan/kaki lima. 


\section{PENDAHULUAN}

Indonesia adalah negara kepulauan yang memiliki banyak potensi yang dapat dikembangkan untuk kemajuan negara. Potensi-potensi tersebut tersebar dari sabang sampai marauke. Negara memiliki kekuasaan untuk mengelola seluruh potensi yang ada untuk mewujudkan kemakmuran negara.

Berdasarkan karakteristik wilayah Indonesia maka salah satu potensi yang prosfek untuk dikembangkan dalam jangka panjang untuk tujuan kemakmuran adalah pengembangan potensi negara pada sektor pariwisata. Secara umum diseluruh wilayah Indonesia memiliki potensi pariwisata dengan keunggulan dan kekhasan masing-masing yang dapat dijadikan prioritas untuk dikembangkan secara terintegrasi dengan multi destinasi dalam satu wilayah. Dalam konsep pengelolaan potensi pariwisata oleh suatu daerah di seluruh wilayah Indonesia harus mengacu pada rencana strategis pengembangan pariwisata nasional dengan tujuan untuk dapat mendorong pertumbuhan ekonomi nasional.

Sektor pariwisata merupakan salah satu sektor terbesar dan terkuat dalam perekonomian Indonesia. Sektor pariwisata menjadi salah satu pendorong utama pertembuhan perekonomian Indonesia karena terdapat beberapa keuntungan selain mampu memberikan devisa cukup besar bagi negara, pariwisata juga dapat memperluas lapangan pekerjaan dan memperkenalkan budaya masing-masing daerah ke mancanegara.

Menurut hasil penelitian Lembaga Penyelidikan Ekonomi dan Masyarakat Fakultas Ekonomi dan Bisnis Universitas Indonesia (2018) Pertumbuhan ekonomi pariwisata memiliki pengaruh terhadap pertumbuhan ekonomi melalui berapa jalur. Pertama, sektor pariwisata sebagai penghasil devisa untuk memperoleh barang modal yang digunakan dalam proses produksi. Kedua, pengembangan pariwisata menstimulus investasi dibidang infrakstruktur. Ketiga, pengembangan sektor pariwisata mendorong pengembangan sektor-sektor ekonomi yang lainnya melalui direct, indirect, dan induced effect. Keempat, pariwisata ikut berkontribusi dalam peningkatan kesempatan kerja dan peningkatan pendapatan. Kelima, pariwisata menyebabkan positive economies of scale. Pariwisata juga merupakan faktor penting dalam penyebaran technical knowledge, mendorong research and development, dan akumulasi modal manusia.

Dengan melihat peran penting sektor pariwisata dalam pertumbuhan ekonomi menjadikan keharusan bagi negara untuk memberikan perhatian yang serius dalam upaya pengembangan sektor pariwisata di seluruh wilayah Indonesia. Rencana strategis pengembangan pariwisata dalam implementasinya diarahkan untuk melakukan pengembangan dibeberapa daerah dengan prioritas pada daerah yang memiliki prosfek menjanjikan serta memiliki daya tarik yang luar biasa bagi para wisatawan. Salah satu daerah yang memenuhi persyaratan tersebut dan menjadi prioritas pengembangan pariwisata nasional adalah Provinsi Nusa Tenggara Barat dengan (KEK) Mandalika.

Salah satu dampak pengembangan pariwisata di Provinsi Nusa Tenggara Barat, dimana pada tahun 2017 Nusa Tenggara Barat menjadi daerah yang mengalami pertumbuhan ekonomi tertinggi diatas rata-rata nasional, dimana pencapaian tingkat pertumbuhan ekonomi tersebut salah satu sektor yang memberikan kontribusi terbesar adalah sektor pariwisata. Tingginya kontribusi sektor pariwisata dapat dilihat juga pada indikator adanya peningkatan kunjungan wisata mancanegara dan wisatawan nusantara dalam lima tahun terakhir ke Provinsi Nusa Tenggara Barat sesuai tabel berikut :

Tabel 1.1 Tingkat Kunjungan Wisata di Provinsi NTB

\begin{tabular}{|c|c|c|c|c|}
\hline NO & TAHUN & WISMAN & WISNUS & JUMLAH \\
\hline 1 & 2014 & 752.306 & 876.816 & 1.629 .122 \\
\hline 2 & 2015 & 1.061 .292 & 1.149 .235 & 2.210 .527 \\
\hline 3 & 2016 & 1.404 .328 & 1.690 .109 & 3.094 .437 \\
\hline 4 & 2017 & 1.430 .249 & 2.078 .654 & 3.508 .903 \\
\hline 5 & 2018 & 1.204 .556 & 1.607 .823 & 2.812 .379 \\
\hline
\end{tabular}

Sumber: Statistik Dinas Pariwisata Provinsi Nusa Tenggara Barat. 
Berdasarkan tabel diatas, dapat dilihat bahwa pada tahun 2014 sampai dengan tahun 2017 tingkat kunjungan wisata mengalami peningkatan yang signifikan, sedangkan pada tahun 2018 mengalami penurunan dengan tingkat kunjungan yang relatif lebih rendah bila dibandingkan dengan tahun sebelumnya. Penurunan ini terjadi karena adanya bencana gempa bumi yang terjadi di Pulau Lombok pada pertengahan tahun 2018 yang membuat wisatawan khususnya luar daerah dan mancanegara menahan diri untuk berkunjung ke Nusa Tenggara Barat. Bencana gempa bumi tersebut juga berpengaruh terhadap kondisi perekonomian daerah secara umum terutama pada menurunnya kontribusi pendapatan daerah dari sektor pariwisata.

Nusa Tenggara Barat memiliki potensi pariwasata yang cukup besar dengan segala keunggulan masing-masing destinasi. Potensipotensi yang ada menjadi salah satu perhatian pemerintah untuk dikembangkan dengan pola perencanaan strategis dan mengakar pada kondisi kearifan yang dimiliki oleh masyarakat lokal. Salah satu bentuk pengembangan yang sedang digalakkan oleh pemerintah adalah pengembangan kawasan wisata Kuta Mandalika yang lebih dikenal dengan (KEK) Madalika. Pada pengembangan kawasan ini diintegrasi dengan beberapa fasilitas pendukung lainnya dimana salah satunya adalah adanya pembangunan Sirkuit Motor GP yang akan beroperasi untuk pertama kalinya pada tahun 2021.

Adanya pengembangan kawasan Pantai Kuta Mandalika menjadi kawasan ekonomi khusus telah memberikan pengaruh pada struktur sosial ekonomi dan budaya masyarakat sekitar. Perubahan yang cukup mendasar yang dapat terlihat langsung adalah munculnya kesadaran masyarakat untuk mulai terlibat dalam aktivitas ekonomi yang muncul sebagai akibat pengembangan kawasan Pantai Kuta Mandalika. Salah satu bentuk keterlibatan masyarakat sekitar dapat dilihat dari sebaran jenis pelaku usaha pariwisata yang telah beroperasional di kawasan Pantai Kuta Mandalika. Berikut data jumlah pelaku usaha pariwisata berdasarkan bidang usaha di Kawasan Pantai Kuta Mandalika tahun 2018 :
Tabel. 1.2. Jumlah Pelaku Usaha Pariwisata Berdasarkan Bidang Usaha di Kawasan Pantai Kuta Mandalika Lombok Tengah NTB

\begin{tabular}{|l|l|c|c|}
\hline NO & \multicolumn{1}{|c|}{ BIDANG USAHA } & JUMLAH & KET \\
\hline 1 & Hotel, Villa, Homestay, Penginapan, Bungalow, dll & 70 & \\
\hline 2 & Restoran, Café, Rumah Makan dan Warung (dil) & 65 & \\
\hline 3 & Kerajinan (Art Shop) & 12 & \\
\hline 4 & Kios/Toko & 26 & \\
\hline 5 & Pemandu Wisata & 5 & \\
\hline 6 & Biro perjalanan & 7 & \\
\hline 7 & Pedagang Asongan & 67 & \\
\hline 8 & $\begin{array}{l}\text { Jasa (SPA, Penyewaan Papan Surfing, Bengkel dan } \\
\text { Massage/Pijat) }\end{array}$ & 8 & \\
\hline & \multicolumn{1}{|c|}{ JUMLAH } & 261 & \\
\hline
\end{tabular}

Sumber: Dinas Koperasi UKM Provinsi Nusa Tenggara Barat

Jumlah pelaku pariwisata tersebut diatas adalah merupakan bentuk partisipasi masyarakat lokal untuk terlibat aktif dalam pengembangan pariwisata di kawasan Pantai Kuta Mandalika. Pengembangan potensi pariwisata kawasan Pantai Kuta Mandalika akan melahirkan banyak peluang yang dapat dimanfaatkan oleh setiap orang. Selain terjadinya pertumbuhan ekonomi yang baik, juga akan berdampak pada aspek penyerapan tenaga kerja, pengembangan sosial, budaya masyarakat, serta mulai diperhatikannya pemenuhan infrastruktur dasar yang memadai dan bergeraknya aktifitas-aktifitas ekonomi masyarakat sekitar lainnya yang pada akhirnya semua akan bermuara pada peningkatan kesejahteraan masyarakat.

Adapun upaya pemerintah yang telah dilakukan dalam rangka pengembangan pariwisata khususnya dikawasan Pantai Kuta Mandalika adalah membangun kesiapan masyarakat untuk menghadapi perubahan dan perkembangan yang akan terjadi, khususnya melalui pengembangan kapasitas sumber daya manusia melalui peningkatan keterampilan skill dan daya saing pelaku usaha.

Dengan adanya pengembangan kawasan Pantai Kuta Mandalika yang sedang digalakkan oleh pemerintah serta adanya dampak positif dan negative yang akan terjadi dari pengembangan pariwisata tersebut, maka peneliti tertarik untuk melakukan penelitian dengan judul "Dampak Pariwisata Terhadap Pengembangan dan Pendapatan Masyarakat di Pantai Kuta Mandalika Desa Kuta Kecamatan Pujut Lombok Tengah". 


\subsection{Rumusan Masalah}

Berdasarkan uraian di atas adapun rumusan masalah yang diidentifikasi dalam penelitian ini adalah sebagai berikut:

1. Bagaimanakah dampak pariwisata terhadap pengembangan masyarakat di Pantai Kuta Mandalika Desa Kuta Kecamatan Pujut Lombok Tengah?

2. Bagaimanakah dampak pariwisata terhadap pendapatan masyarakat di Pantai Kuta Mandalika Desa Kuta Kecamatan Pujut Lombok Tengah?

\subsection{Tujuan Penelitian}

Adapun tujuan penelitian yang ingin dicapai dari penelitian ini adalah sebagai berikut:

1. Untuk mengetahui bagaimana pengembangan pariwisata di Pantai Kuta Mandalika Desa Kuta Kecamatan Pujut Lombok Tengah.

2. Untuk mengetahui bagaimana pendapatan masyarakat di Pantai Kuta Mandalika Desa Kuta Kecamatan Pujut Lombok Tengah.

1.4.Manfaat penelitian

Adapun manfaat yang diharapkan dari penelitian ini adalah sebagai berikut:

1. Dapat menambah wawasan pengetahuan tentang pengembangan pariwisata di Pantai Kuta Mandalika Desa Kuta Kecamatan Pujut Lombok Tengah.

2. Memberikan gambaran mengenai pengembangan dan pendapatan masyarakat di Pantai Kuta Mandalika Desa Kuta Kecamatan Pujut Lombok Tengah.

3. Memberikan informasi bagi pemerintah dalam melakukan pengembangan pariwisata di Provinsi Nusa Tenggara Barat.

4. Menjadi bahan kajian dalam penelitian lebih lanjut.

\section{TINJAUAN PUSTAKA}

\subsection{Penelitian Terdahulu}

Dalam menelusuri sebuah masalah perlu ada pedoman yang digunakan untuk dapat membantu dalam pelaksanaan penelitian. Untuk menghindari adanya duplikasi, plegmasi, replikasi dan menjamin keaslian dan keabsahan penelitian yang dilakukan. Di sini penulis akan meneliti Dampak Pariwisata Terhadap Pengembangan dan Pendapatan Masyarakat di Pantai Kuta Mandalika Desa Kuta Kecamatan Pujut Lombok Tengah. Untuk menghindari duplikasi, penulis telah melakukan penelusuran terhadap karya ilmiah-karya ilmiah terdahulu yang dapat membantu memberikan data yang valid pada penulis. Berikut beberapa penelitian yang telah ditelusuri oleh penulis:

Pertama Sa'idah (2017) melakukan penelitian tentang analisis strategi pengembangan pariwisata dalam menigkatkan pendapatan asli daerah pada Kota Bandar Lampung, menemukan bahwa pengembangan pariwisata dapat dikatakan tidak semua terlaksana dengan maksimal karena saat ini belum ada obyek wisata yang dikelola secara mandiri oleh Dinas Pariwisata melainkan masih dikelola secara pribadi oleh masyarakat.

Kedua Anggraeni (2018) melakukan penelitian tentang dampak pengembangan industri pariwisata terhadap kondisi ekonomi masyarakat sekitar, menemukan bahwa pengembangan berdampak pada kehidupan masyarakat sekitar. Salah satu dampak dari pengembangan pariwisata di Merak Belantung adalah dibangunnya fasilitas komersial dikawasan pariwisata. Tingkat pendidikan masyarakat meningkat dengan semakin banyaknya masyarakat yang melanjutkan pendidikan hingga perguruan tinggi.

Ketiga Maharani (2014) melakukan penelitian tentang Pengembangan Potensi Pariwisata Kabupaten Sumenep, menemukan terdapat kendala-kendala yang dihadapi oleh pemerintah dalam pengembangan potensi pariwisata yang terjadi di Pantai Sumenep, Pariwisata diharapkan mampu memberikan dampak yang positif bagi dunia pariwisata Indonesia secara khusus.

\subsection{Landasan Teori}

\subsubsection{Pengertian Pariwisata}

Secara etimologi, kata pariwisata berasal dari bahasa Sansekerta yang terdiri atas dua kata yaitu pari dan wisata. Pari berarti "banyak" atau "berkeliling", sedangkan wisata berarti "pergi" atau "bepergian". Atas dasar itu, maka kata pariwisata seharusnya diartikan 
sebagai perjalanan yang dilakukan berkali-kali atau berputar-putar, dari suatu tempat ke tempat lian. yang dalam bahasa Inggris disebut dengan kata "tour", sedangkan untuk pengertian jamak, kata "Kepariwisataan" dapat digunakan kata "tourisme" atau "tourism" Yoeti (dalam Widyatmaja dan I Ketut 2017).

Dalam kamus besar bahasa Indonesia dikemukakan bahwa pariwisata adalah suatu kegiatan yang berhubungan dengan perjalanan rekreasi. Istilah pariwisata pertama kali digunakan pada tahun 1959 dalam Musyawarah Nasional Turisme II di Tretes, Jawa Timur. Istilah ini dipakai sebagai pengganti kata Turisme sebelum kata pariwisata diambil dari bahasa Sansekerta. Untuk mendapatkan gambaran yang lebih jelas, lebih lanjut Yoeti (dalam Widyatmaja dan I Ketut 2017) memberikan suatu batasan tentang penyebaran kata-kata sebagai berikut:

1. Wisata yang berarti perjalanan, dalam bahasa Inggris dapat disamakan dengan perkataan "travel".

2. Wisatawan, yang berarti orang yang melakukan perjalanan; dalam bahasa

Inggris dapat disebut dengan istilah "travellers".

3. Para wisatawan, yang berarti orang-orang yang melakukan perjalanan dalam bahasa Inggris biasa disebut dengan istilah "travellers" (jamak).

4. Pariwisata, yang berarti perjalanan yang dilakukan dari suatu tempat ke tempat lain dan dalam bahasa Inggris disebut "tourist".

5. Para pariwisatawan, yang berarti orang yang melakukan perjalanan tour dan dalam bahasa Inggris disebut dengan istilah "tourists" (jamak).

6. Kepariwisataan, yang berarti hal-hal yang berhubungan dengan pariwisata dan dalam bahasa Inggris disebut dengan istilah "tourism".

\subsubsection{Jenis dan Macam Pariwisata}

Kepariwisataan tidak menggejala sebagai bentuk tunggal. Istilah ini umum sifatnya yang menggambarkan beberapa jenis perjalanan dan penginapan sesuai dengan motivasi yang mendasari kepergian tersebut.
Orang melakukan perjalanan untuk memperoleh berbagai tujuan dan memuaskan bermacam-macam keinginan. Di samping itu, untuk keperluan perencanaan dan pengembangan kepariwisataan itu sendiri, perlu pula dibedakan antara pariwisata dengan jenis pariwisata lainnya, sehingga jenis dan macam pariwisata yang dikembangkan akan dapat berwujud seperti diharapkan dari kepariwisataan itu sendiri. Sebenarnya pariwisata sebagai suatu gejala, terwujud dalam beberapa bentuk yang antara lain, misalnya :

a. Menurut letak geografis, dimana kegiatan pariwisata berkembang dibedakan menjadi

1. Pariwisata lokal (local tourism) yaitu jenis kepariwisataan yang ruang lingkupnya lebih sempit dan terbatas dalam tempat-tempat tertentu saja. Misalnya kepariwisataan kota Denpasar, kepariwisataan kota Bandung.

2. Pariwisata regional (regional tourism) yaitu kegiatan kepariwisataan yang dikembangkan dalam suatu wilayah tertentu, dapat regional dalam lingkungan nasional dan dapat pula regional dalam ruang lingkup internasional. Misalnya kepariwisataan Bali, Yogyakarta, dan lain-lain.

3. Pariwisata nasional (national tourism) yaitu jenis pariwisata yang dikembangkan dalam wilayah suatu negara, dimana para pesertanya tidak saja terdiri dari warganegaranya sendiri tetapi juga orang asing yang terdiam di negara tersebut. Misalnya kepariwisataan yang ada di daerahdaerah dalam satu wilayah Indonesia.

4. Pariwisata regional-internasional yaitu kegiatan kepariwisataan yang berkembang di suatu wilayah internasional yang terbatas, tetapi melewati batas-batas lebih dari dua atau tiga negara dalam wilayah tersebut. Misalnya kepariwisataan ASEAN.

5. Pariwisata internasional (International tourism) yaitu kegiatan kepariwisataan yang terdapat atau dikembangkan dibanyak negara di seluruh dunia. 


\subsubsection{Pengertian Pendapatan}

Pengertian pendapatan merupakan uang bagi sejumlah pelaku usaha yang telah diterima oleh suatu usaha dari pembeli sebagai hasil dari proses penjualan barang maupun jasa. Pendapatan atau dapat disebut dengan keuntungan ekonomi merupakan pendapatan total yang diperoleh pemilik usaha setelah dikurangi biaya produksi sukirno (dalam Tua Ronatal Sianturi 2018).

Menurut Sukirno (2011) pendapatan adalah jumlah penghasilan yang diterima oleh penduduk atas kerjanya selam satu periode tertentu, baik harian, mingguan, bulanan maupun tahunan. Beberapa klasifikasi pendapatan antara lain:

1. Pendapat Pribadi, yaitu semua jenis pendapatan yang diperoleh tanpa memberikan suatu kegiatan yang diterima penduduk suatu Negara.

2. Pendapatan Desposebel, yaitu pendapatan pribadi dikurangi pajak yang harus dibayarkan oleh para penerima pendapatan.

3. Pendapatan Nasional, yaitu nilai seluruh barang-barang jadi dan jasa-jasa yang diproduksikan oleh suatu Negara dalam satu tahun.

Pada hakikatnya pendapatan yang diterima oleh seseorang maupun badan usaha tentunya dipengaruhi oleh banyak faktor, seperti tingkat pendidikan dan pengalaman maka makintinggi pula tingkat pendapatannya. Kemudian juga tingkat pendapatan sangat dipengaruhi oleh modal kerja, jam kerja, akses kredit, jumlah tenaga kerja, tanggungan keluarga, jenis barang dagangan (produk) dan faktor lainnya. Pada umumnya masyarakat selalu mencari tingkat pendapatan tinggi untukk memenuhi kebutuhan rumah tangganya, akan tetapi dibatasi oleh beberapa faktor tersebut yaitu:

1. Pendapatan ekonomi, adalah sejumlah uang yang dapat digunakan oleh keluarga dalam suatu periode tertentu untuk membelanjakan diri tanpa mengurangi atau menambah asset netto (net asset), termasuk dalam pendapatan ekonomi upah gaji, pendapatan bunga deposito, penghasilan transfer dari pemerintah dan lain-lain.
Pendapatan uang adalah sejumlah uang yang diterima keluarga pada periode tertentu sebagai bals jasa atau faktor produksi yang diberikan karena tidak memperhitungkan pendapatan, terutama penghasilan transfer cakupannya lebih sempit dari pendapatan ekonomi.

\section{METODE PENELITIAN}

\subsection{Pendekatan Penelitian}

Dalam penelitian ini menggunakan jenis penelitian deskriptif kualitatif. Penelitian kualitatif adalah penelitian tentang riset yang bersifat deskriptif dan cenderung menggunakan analisis. Kemudian penelitian deskriptif adalah salah satu jenis penelitian yang tujuan untuk menyajikan gambaran lengkap mengenai fenomena yang terjadi secara sistematis, aktual dan akurat sesuai fakta yang ada dengan mengumpulkan data, menjelaskan dan melakukan analisa secara obyektif yang artinya hasil penelitian ini akan lebih menekankan pada gambaran mengenai objek peneliti yang riil atau sebenarnya.

\subsection{Tempat dan Objek Penelitian}

Penelitian ini dilakukan pada obyek wisata Pantai Kuta Mandalika Desa Kuta Kecamatan Pujut Lombok Tengah.

\subsection{Teknik Pengumpulan Data}

Teknik pengumpulan data yang digunakan dalam penelitian ini adalah teknik observasi, wawancara dan dokumentasi, secara singkat teknik pengumpulan

\subsection{Teknik analisa Data}

Analisis data kualitatif (Bogdan \& Biklen 1982) adalah upaya yang dilakukan jalan bekerja dengan data, mengorganisasikan data, memilih-milihnya menjadi satuan yang dapat dikelola, mensintesikannya, mencari dan menemukan pola, menemukan apa yang penting dana pa yang dipelajari dan memutuskan apa yang dapat diceritakan kepada orang lain.

\subsection{Jenis dan Sumber Data}

Menurut Lofland dan Lofland (dalam Moleong 2010) sumber data utama dalam penelitian kualitatif adalah kata-kata, dan tundakan selebihnya adalah data tambahan seperti dokumen dan lain-lain. Berkaitan dengan hal itu pada bagian ini jenis datanya 
dibagi kedalam kata-kata dan tindakan, sumber data tertulis, foto dan statistik.

\section{HASIL DAN PEMBAHASAN}

\subsection{Gambaran Umum Lokasi Penelitian 4.1.1. Letak Geografis}

Kabupaten Lombok Tengah merupakan salah satu Kabupaten dari 10 (sepuluh) Kabupaten/Kota yang ada di Provinsi NTB. Hingga Tahun 2018 di Kabupaten Lombok Tengah tercatat terdapat sebanyak 12 kecamatan dengan luas wilayah berkisar antara 50 hingga $234 \mathrm{~km}^{2}$. Kecamatan dengan luas wilayah terluas yakni Kecamatan Pujut, yang mencapai $19,33 \%$ dari luas wilayah Kabupaten, diikuti Kecamatan Batukliang Utara, Praya Barat dan Praya Barat daya dengan presentase masing-masing $15,06 \%$, $12,64 \%$ dan 10,34\%, sementara itu kecamatan-kecamatan lainnya memiliki presentase luas wilayah dibawah $7 \%$. Secara historis keberadaan Lombok Tengah terbentuk sejak dikeluarkannya Stb Nomor: 248 Tahun 1898, kemudian pasca proklamasi, Lombok Tengah secara Integral menjadi bagian dari Negara Kesatuan Republik Indonesia (NKRI) ditandai dengan pelantikan secara formal oleh Kepala Pemerintah setempat yang pertama pada tanggal 15 Oktober 1945.

Tabel 4.1.2 Dampak Pengembangan Pariwisata

\begin{tabular}{|c|l|c|c|c|}
\hline No & \multicolumn{1}{|c|}{ Uraian } & Jumlah Orang & Presentase (\%) & Ket \\
\hline 1 & Bidang Ekonomi & & & \\
\hline & - Ya & 40 & 100 & \\
\hline & - Tidak & 0 & 0 & \\
\hline 2 & Bidang Sosial dan Budaya & & & \\
\hline & - Ya & 25 & 62.5 & \\
\hline & - Tidak & 15 & 37.5 & \\
\hline 3 & Bidang Lingkungan & & & \\
\hline & - Ya & 21 & 52.5 & \\
\hline & - Tidak & 19 & 47.5 & \\
\hline
\end{tabular}

Sumber: Data primer dan diolah

Berdasarkan tebel diatas dapat di jelasakan bahwa 40 orang pelaku usaha pariwisata menyatakan bahwa pariwisata berdampak terhadap pengembangan masyarakat di dalam bidang ekonomi. Sedangkan dampak pariwisata terhadap pengembangan masyarakat dalam bidang sosial budaya menyatakan bahwa 62.5 b. atau sekitar 25 orang menyatakan berdampak dan $37.5 \%$ atau 15 orang menyatakan tidak berdampak ke bidang sosial budaya.

Dampak pariwisata dalam bidang lingkungan dari seluruh responden menyatakan bahwa 21 orang atau sekitar 53,5 $\%$ menyatakan bahwa pariwisata berdampak pada lingkungan baik dalam bentuk penataan lingkungan dan juga kerusakan lingkungan, sedangan sisanya 19 orang atau $47.5 \%$ menyatakan tidak berdampak pada lingkungan.

Table 4.1.3. Rata-Rata Omset, Biaya Dan Pendapatan Pelaku Usaha Pariwisata

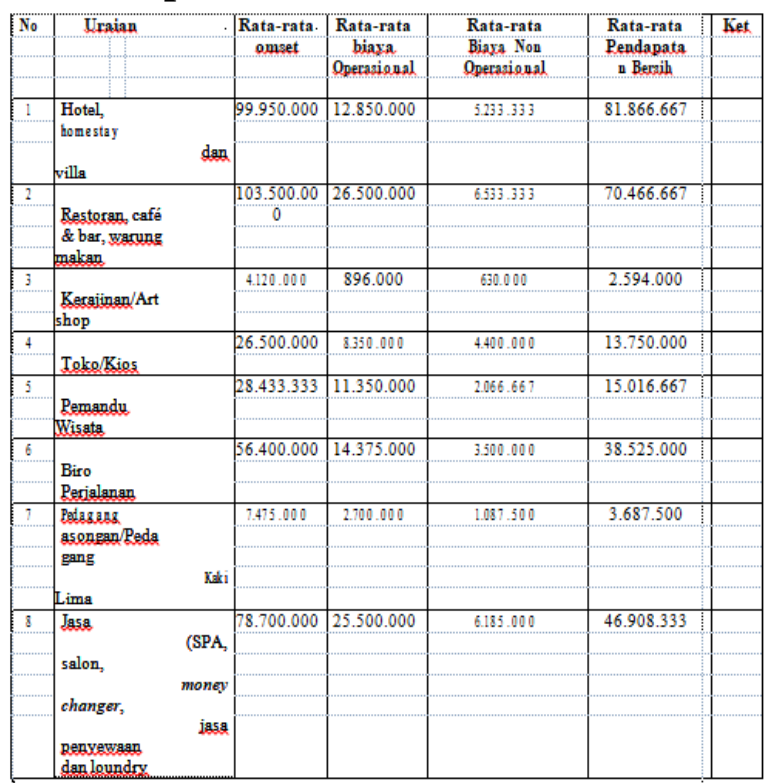

Sumber: Data primer dan diolah

Dari hasil penelitian menunjukkan bahwa terdapat perbedaan tingkat rata-rata omset dalam sebulan masing-masing kelompok jenis usaha pelaku usaha pariwisata di kawasan Pantai Kuta Mandalika. Jenis usaha hotel, homestay villa dan bungalow rata-rata omset perbulannya adalah sebesar Rp. 99.950.000 dengan biaya operasional yang dikeluarkan sebesar Rp. 12.850.000 dan biaya non operasional sebesar Rp. 5.233.333 sehinga pelaku usaha untuk jenis usaha hotel, homestay villa dan bungalow rata-rata mendapatkan pendapatan bersih sebesar $\mathrm{Rp}$. 81.866.667.

Secara umum tingkat omset usaha pada usaha tersebut di pengaruhi oleh tingkat jumlah kamar, tipe hotel dan rata-rata 
kunjungan perhari termasuk juga event-event yang diselenggarakan di kawasan pantai Kuta Mandalika. Dalam pariwisata dikenal istilah High Season dan Los Season yang merujuk pada tinggi rendahnya tingkat kunjungan wisata pada waktu-waktu tertentu.

Jenis usaha restoran, cafe dan bar, warung makan memiliki tingkat rata-rata omset sebesat Rp. 103.500.000 dengan rata biaya operasional Rp. 26.500.000 dan biaya non operasional sebesar Rp. 6.533.333 dan rata-rata pendapatan bersih sebesar Rp. 70 . 466.000. Tingganya tingkat pendapatan bersih dari jenis usaha tersebut lebih banyak dibentuk oleh tingginya tingkat pendapatan bersih yang di peroleh okeh jenis usaha restoran, cafe dan bar sedangkan untuk jenis usaha warung makan tidak memberikan kontribusi yang signifikant dalam membentuk tingkat omset dan pendapatan bersih jenis usaha restoran, cafe dan bar, warung makan.

Jenis usaha kerajinan/artshop tingkat omset rata-rata sebesar Rp. 4.120 .000 perbulan dengan rata-rata biaya operasional sebesar Rp. 896.000 dan rata-rata biaya non operasional sebesar 630.000 untuk setiap bulannya. Jenis usaha Kerajinan/Artshop ratarata pendapatan bersih sebesar Rp. 2.594.000 perbulan. Pelaku usaha pariwisata kerajinan/artshop mengeluhkan adanya penurunan pendapatan bersih dari kondisi sebelum pengembangan pariwisata di kawasan pantai kuta mandalika. Menurut responden pelaku usaha pariwisata bidang kerajinan/artshop mengalami penurunan karena adanya penurunan minat

\subsection{Pembahasan}

Pariwisata di Kawasan Pantai Kuta Mandalika adalah merupakan salah satu destinasi wisata yang ada di Provinsi Nusa Tenggara Barat yang dikembangkan menjadi Kawasan Ekonomi Khusus (KEK) yang kemudian lebih dikenal dengan KEK Mandalika.

Pengembangan Pantai Kuta Mandalika meliputi unsur pengembangan bidang atraksi, pengembangan bidang transportasi, bidang fasilitas pelayanan dan infrastruktur. Pegembangan pariwisata di Kawasan Pantai Kuta Mandalika memberikan dampak perubahan terhadap kondisi ekonomi, sosial budaya dan lingkungan di Desa Kuta Kecamatan Pujut Kabupaten Lombok Tengah.

Berdasarkan hasil penelitian yang di lakukan bahwa aktivitas pariwisata di Kawasan Pantai Kuta Mandalika memberikan dampak terhadap pengembangan kondisi ekonomi masyarakat dalam bentuk perubahan struktur ekonomi masyarakat yang sebelumnya lebih dominan dalam bidang pertanian dan perikanan sekarang berkembang pada aktivitas ekonomi masyarakat dalam bidang kepariwisataan.

\section{KESIMPULAN}

Berdasarkan penelitian tentang dampak pariwisata terhadap pengembangan dan pendapatan masyarakat Di Pantai Kuta Mandalika Desa Kuta Kecamatan Pujut Lombok Tengah diambil kesimpulan sebagai berikut :

1. Pariwisata berdampak terhadap pengembangan masyarakat di Pantai Kuta Mandalika Desa Kuta Kecamatan Pujut khususunya dalam bidang ekonomi, sosial budaya dan lingkungan. Masyarakat terlibat aktif dalam aktivitas pariwisata yang dikembangkan di Kawasan Pantai Kuta Mandalika.

2. Pariwisata berdampak terhadap pendapatan masyarakat di Pantai Kuta Mandalika Desa Kuta Kecamatan Pujut untuk pelaku usaha pariwisata hotel, restoran, pemandu wisata, biro perjalanan, toko dan usaha jasa pariwisata dalam peningkatan kapasitas usaha dan memberikan dampak penurunan terhadap kapasitas usaha bagi pelaku usaha pariwisata kerajinan/artshop, pedangan asongan/kaki lima. Pengembangan pariwisata di Kawasan Pantai Kuta Mandalika membuka peluang invetasi bagi pelaku usaha besar dan menjadi ancaman bagi pelaku usaha lokal yang tidak mampu beradaptasi dan bersaing dengan pengembangan yang terjadi.

\section{SARAN}

Berdasarkan hasil penelitian diatas, maka saran yang dapat digunakan adalah:

1. Pemerintah desa dapat memberikan sosialisasi terkait pentingnya 
mengembangkan dan mengelola suatu kawasan wisata untuk meningkatkan pendapatan pelaku usaha maupun masyarakat secara umum.

2. Pemerintah desa senantiasa memberikan pelaihan khusus tentng berwirausaha bagi pelaku usaha.

3. Pelaku usaha atau masyarakat secara umum harus cepat dalam membaca peluang usaha.

4. Diharapkan dapat menjadi bahan referensi dan pertimbangan bagi peneliti agar lebih mengenali dampak pariwisata terhadap pengambangan dan pendapatan masyarakat di Pantai Kuta Mnadalika Lombok Tengah Pengembangan pariwisata oleh pemerintah diharapkan untuk memperkuat kearifan lokal dan memberikan ruang yang lebih luas kepada masyarakat lokal. Agar identitas dan nilai-nilai daerah dapat terus di pertahankan.

\section{DAFTAR PUSTAKA}

Anggraeni, Rani puspita, 2018. Dampak Pengembangan Industri Pariwisata Terhadap Kondisi Ekonomi Masyarakat Sekitar. Universitas Lampung: Bandar Lampung. Diakses melalui digilib.unila.ac.id

Bogdan, Biklen. 1982. Qualitative reseach for education: An. Introduction to

Theory and Methode, Boston: Allyn and Bacon, Inc.

Dewi, Rismanti. 2002. Pengantar Mikro Sektor Pariwisata. Jurnal. Nganjuk.

Dinas Pariwisata Provinsi NTB, 2017. Standarisasi Usaha Jasa Pariwisata, Bidang Pengembangan Destinasi: Mataram.

DinasKebudayaan Pariwisata Provinsi NTB, 2016. Direktori Data Usaha Pariwisata Nusa Tenggara Barat: Mataram.

Dinas, Kebudayaan Pariwisata. 2019. Angka Kunjungan Wisatawan ke NTB, Diakses pada tanggal 20 Desember 2019.

Melalui http//disbudpar.ntbprov.go.id

Wijayanto, Agus, D. 2018. Kecamatan Pujut Dalam Angka. Koordinator Statistik Kecamatan Pujut/Badan Pusat Statistik Kabupaten Lombok Tengah.
Diakses

melalui http://lomboktengahkab.bps.go.id

Fendeli, Chafid. 1995. Dasar-dasar Manajemen Kepariwisataan Alam. Penerbit Liberty. Yogyakarta.

Hadjar, Hotman. 2002. Metode Penelitian Kualitatif Perspektif Mikro. Insan Cendikia: Surabaya.

Kementrian Pariwisata, 2019. Program Unggulan Ekonomi Pariwisata Pertanian Industri. Diakses pada Tanggal 21 Desember 2019. Diakses Melalui https://www.ntbprov.go.id.

Kusudianto Hadinoto. 1996. "Perencanaan Pengembangan Destinasi Pariwisata.Jakarta: UI Press.

Lofland \& Lofland, Moleong J. 2011. Metodologi Penelitian Kualitatif. Edisi Revisi. PT Remaja Rosdakarya: Bandung.

Maha, Rani Deddy Prasetyo. 2014. Pengembangan Potensi Pariwisata. Universitas Airlangga. Jurnal Politik Muda, 3 (3), 412-421. Diakses pada Agustus-Desember: Jawa Timur. Diakses melalui. Journal.unair.ac.id

Miles and Huberman. 1984. Qualitatif Data Analysis a Sourcebok Of New Methode. London: Sage Publications.

Moleong, J lexy. 2010. Metodologi Penelitian Kualitatif Edisi Revisi. PT Remaja Rosdakarya: Bandung.

Moerdijat, Lestari. 2019. Kajian Dampak Sector Pariwisata Terhadap Perekonomian Indonesia. Diakses pada tanggal 22 Desember 2019. Melalui www//kemenpar.go.id.

Nazir, M. 1999. Metode Penelitian cetakan keempat. Jakarta: Ghalia Indonesia.

Hasibuan, Rinaldi, M N. 2018. Dampak Perkembangan Pariwisata Terhadap Kondisi Sosial Ekonomi Masyarakat. Universitas Sumatera Utara: Medan. diakses melalui. http//respositori.usu.ac.id/handle

Nyoman, S.P, 2003. Ilmu Pariwisata Sebuah Pengantar Perdana. Gramedia Pustaka Utama: Jakarta. 
Terakreditasi Peringkat 5 (No. SK: 85/M/KPT/2020)

Pitana, I.G \& Putu G. 2005. Sosiologi pariwisata. CV. Andi Offset: Yogyakarta.

Pemerintah Indonesia, Undang-Undang Nomor 10 Tahun 2009. Tentang Kepariwisataan. Lembaran Negara Republik Indonesia Tahun 2019 No.11. Sekretariat Negara: Jakarta.

Pemerintah Indonesia. Undang-Undang Nomor 9 Tahun 1990 Tentang Kepariwisataan. Lembaran Negara Republik Indonesia No. 78 Sekretariat Negara: Jakarta.

Pitana, Tua Ronatal 2018. Dampak Perkembangan Pariwisata Terhadap Pendapatan pelaku Usaha Wisata Bukit Indah Simarjarunjung Kabupaten Simalungun. Diakses melalui ejournal.ac.id

Pitana \& Gayatri. 2005. Sosioolgi Pariwisata. CV. Andi Offset: Yogyakarta.

Profil Desa Kuta. 2019. Hasil penelitian Lapangan. Desa Kuta Kecamatan Pujut

Lombok tengah. Pada hari Kamis: Lombok Tengah

Putri, Rezi Kurnia. 2015. Pengembangan Pariwisata Oleh Dinas Kebudayaan Pariwisata dan DISBUDPAR Universitas Andalas: Padang. Diakses Melalui. Scholar.unand.ac.id Tanggal 16 Januari 2019

Ratnaningsih. 2015. Partisipasi Masyarkat Lokal Dalam Pariwisata (Studi Kasus Di Desa Belimbing, Tabanan, Bali). Jurnal Destinasi Pariwisata. Universitas Udayana.

Sa'idah, Afrianti Nur, 2017. Analisis Starategi Pengembangan Pariwisata Dalam Meningkatkan Pendapatan Asli Daerah. Universitas Islam negeri Raden Intan: Lampung. Diakses melalui: Respository.Radenintan.ac.id

Saifullah. 2002. Kajian Pengembangan Pariwisata Bahari dan Kontribusinya Pada Kesejahteraan Masyarakat pesisir di Pulau Weh (Sabang), Bogor: Progam Pascasarjana, Institut Pertanian Bogor. Melalui [Tesis]
Situmorang, Rahel. 2001. Perencanaan dan Pengembangan Wisata Pantai Berwawasan Lingkungan. Bina wisata nusantara.

Spillane, J. 1987. Pariwisata Indonesia Sejarah Dan Prospeknya. Kanisius:Yogyakarta.

Sugiyono. 2012. Metode Penelitian Kuantitatif, Kualitatif dan R\&D. Bandung:Alfabeta.

Sugiyono, 2010. Memahami Penelitian Kualitati. Bandung: Alfabeta.

Sukirno, Sianturi T. R. 2019. Dampak Perkembangan Pariwisata terhadap pendapatan Pelaku Usaha wisata Bukit Indah Simarjarunjung Kabupaten simalungun. Universitas atma Jaya: Yogyakarta. Diakses melalui ejournal.uajy.ac.id

Suwantoro, Gamal. 2002. Dasar-dasar Pariwisata.: Yogyakarta.

Swarbrooke. 1996. Pengembangan Pariwisata. Gramedia Pustaka Utama: Jakarta. Melalui http://www.scribd.com

Wardiyanta, Anggraini R, 2018. Dampak Pengembangan Industri Pariwisata Terhadap Kondisi Ekonomi Masyarakat Sekitar. Universitas Lampung: Bandar Lampung. Diakses melalui digilib.unila.ac.id

Weber, Ali S. 2016. Strategi Pengembangan Fasilitas Guna Meningkatkan Daya

Tarik Minat Wisatawan Di Darajat Pass. Universitas Pendidikan Indonesia. Diakses melalui respositori.upi.edu/perpustakaan.upi.edu

Yoeti, Oka A. 1996. Pengantar Ilmu Pariwisata. Bandung: Angkasa.

Yeoti, Widyatmaja, I. K. 2017. Pengetahuan Dasar Ilmu Pariwisata. Cetakan Edisi Revisi. Pustaka Larasan. Universitas Udayana: Denpasar Bali. 